\title{
EFFECT OF DRYNESS AND STARVATION ON SOME BIOLOGICAL ASPECTS OF THE BROWN GARDEN LAND SNAILS EOBAANIA VERMACULATA
}

\author{
MOHAMED, GHADA R. ${ }^{1}$, T. M. S. KESHTA ${ }^{2}$, A. A. M . ABO-HASHEM ${ }^{2}$ \\ 1. plant protection Department, Faculty of Agriculture, Moshtahor Benha \\ University \\ 2. Plant Protection Research Institute, $A R C$, Dokki Giza
}

(Manuscript received 21 January 2013)

\begin{abstract}
The effect of dryness and different periods of starvation on E.vermeculata were studied. Results revealed that famine and dryness affect on the weight and mortality of all stages of this snail particularly three months stage, while adults were the most support to these factors. Data indicated also that this treatments were more impressive on the number of clutches, the number of eggs in each clutch, depth of clutch in the soil and solitary eggs deposited. The snail laid the most number of the eggs when it fed every 2 days under $80-85 \%$ soil moisture. On the other hand, adults of this snail were compelled to lay their eggs on surface of the soil under dryness conditions.
\end{abstract}

\section{INTRODUCTION}

Phylum mollusk is probably the third most important animal pest group after arthropods and vertebrates. They were known as destructive pests causing damage to vegetable and field crops (Ghamry et al. 1993, Kassab and Daoud 1994, El- Deeb et al., 1996, Hegab et al. 1999 and Mahrous et al.2002). Land snail is a common name of the numerous species that live on land, as apposed to those that live in Salter and fresh water. One of the important land snail species is $E$. vermiculata, an airbreathing and terrestrial snail. The color of shell is very variable..The life- span of the snail species durate from 2-5 years which make it grow from a minor concern to a major concern for native gastropod species, garden plants and agricultural crops a like (Notton 2006). Ecological conditions play important role in the distribution and biology of this snail. The aim of the present work was directed to study the effect of some ecological factors (dryness and starvation) on certain biological aspects of the garden land snail E. vermicultata.

\section{MATERIALS AND METHODS}

\section{1- Rearing method}

The Snails were hand-collected from swallow plants, (Faculty of Agriculture' Moshtohor farm,) Toukh district, Kalubia Governorate. The snails were put in muslin cloth bags, transfured to the laboratory and washed by water. Healthy adult 
individuals were selected and every 20 snails were put in awooden box containing 9 $\mathrm{cm}$ of mud with high humidity $(80 \%)$. The boxes were covered with muslin cloth to prevent snails from escaping. Snails were fed three time / week with fresh washed lettuce leaves. Ten replicates were used and the soil was changed every 2 days with newly one when it become dirty. The individuals were continually observed until mating and egg-laying. The eggs were removed to a small plastic cups containing moist soil, covered with dark muslin cloth and kept under room temperature until egg hatching .Date of eggs hatching were recorded to separate stages of snail. Four stages were used $(3,6,9,14$ months).

\section{2- The effect of starvation on weight of $E$. vermiculata snail under laboratory conditions}

Four ages of the snail were selected for this trial (three, six, nine and fourteen months). Forty healthy individuals of every stage were chosen. Four levels of starvation (feeding each two days, each week, each month, and without feeding) were used .Ten snails were used for each level of feeding of each stage. All snail stages were kept on soil with $80 \%$ moisture.

\section{3- The starvation and dryness effect on weight and death of $E$. vermiculate under laboratory conditions.}

Four levels of nourishing snails were selected ( nourishing every two days, every week, every month and snails without foods). Ten individuals were used for every level from each stage ( $3,6,9,14$ months). Two levels of soil moisture (80$85 \%$ and $10-15 \%$ ) were considered with the four starvation level. Snails were fed on lettuce leaves. The trial was kept under laboratory conditions. Weight of snails and mortality percentages were calculated. The percentage of mortality was recorded according to this equation:

Percentage of snail death $=$ No. of dead snails $\mathrm{x} 100$ The total No. of snails

\section{4- Effect of starvation and dryness on the number and the depth of $E$. vermiculata eggs in the soil under laboratory conditions.}

Snails used in this experiment were adults stage only. Five healthy pairs were used which each level of feeding (every two days, every week, every month and without food). Snails were obsarved until matting. After matting, number of solitary eggs, egg masses, the number of eggs in each mass and the depth of eggs in the soil were recorded. This trial was run under two levels of soil moisture $(80-85 \%$ and $10-$ $15 \%$ moisture) Each pair was kept in small plastic cup containing $7 \mathrm{~cm}$ of soil and covered with white cloth with rubber band. 


\section{RESULTS AND DISCUSSION}

\section{1- Effect of famish levels on weight of $E$. vermiculata snail under laboratory conditions:}

Data in table (1) illustrated that the different levels of starvation have different effects on the weight of all tested $E$. vermiculata stages under laboratory conditions, especially 3 months age. The highest weight was registered when the snail was eating every two days with means $0.71,1.54,2.80$ and $4.78 \mathrm{~g}$ for $3.6,9$ and 14 months respectively. These weights decreased recording $0.15,0.57,1.29$ and $3.05 \mathrm{grm}$ for the same stages respectively when the snail were prevented from feeding. It is clear that there were significant differences in all tested stages $3,6,9$ and 14 months.

Results revealed that nutrition play an important role for increasing snail weight. As a general trend The increase of food diet correlated positively with the increase of snail weight in all ages.

These Results agreed to some extend with those of Ismail (2004) who studied the effect of certain host plant leaves or potato slices on shell growth of Eobania vermicuata during 12 months under laboratory conditions. The tested food materials can be arranged in order of suitability as follows potato, lettuce, cabbage, navel orange, banana and mango.

Table 1. Effect of famish levels on E. vermiculata weight under laboratory conditions.

\begin{tabular}{|c|c|c|c|c|c|c|c|c|c|c|}
\hline \multirow{2}{*}{\multicolumn{2}{|c|}{$\begin{array}{l}\text { famish level } \\
\text { Snails age }\end{array}$}} & \multirow{3}{*}{$\begin{array}{c}\mathrm{F} 1 \\
0.71\end{array}$} & \multirow{3}{*}{$\begin{array}{c}\mathrm{F} 2 \\
0.61\end{array}$} & \multirow{3}{*}{$\begin{array}{c}\mathrm{F3} \\
0.32\end{array}$} & \multirow[b]{2}{*}{ F4 } & \multirow{2}{*}{$\begin{array}{c}\text { General } \\
\text { mean } \pm \\
\text { S.E }\end{array}$} & \multicolumn{3}{|c|}{ Significance } & \multirow{3}{*}{$\begin{array}{l}\text { L.S.D } \\
0.05= \\
0.289\end{array}$} \\
\hline & & & & & & & $6 m$ & $9 m$ & $14 m$ & \\
\hline \multirow{5}{*}{ 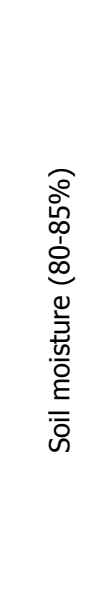 } & 3 months & & & & 0.15 & $\begin{array}{l}0.45 \\
\pm 0.1\end{array}$ & $\begin{array}{l}+++ \\
0.58\end{array}$ & $\begin{array}{l}+++ \\
1.53\end{array}$ & $\begin{array}{l}+++ \\
3.53\end{array}$ & \\
\hline & 6 months & 1.57 & 1.20 & 0.81 & 0.57 & $\begin{array}{l}1.03 \\
\pm 0.1\end{array}$ & - & $\begin{array}{l}+++ \\
0.95\end{array}$ & $\begin{array}{l}+++ \\
2.95\end{array}$ & \multirow[t]{2}{*}{$\begin{array}{l}\text { L.S.D. } \\
0.01= \\
0.380\end{array}$} \\
\hline & 9 months & 2.80 & 2.27 & 1.55 & 1.29 & $\begin{array}{l}1.98 \\
\pm 0.1\end{array}$ & - & - & $\begin{array}{l}+++ \\
2.00\end{array}$ & \\
\hline & $\begin{array}{c}14 \\
\text { months }\end{array}$ & 4.78 & 4.57 & 3.53 & 3.05 & $\begin{array}{l}3.98 \\
\pm 0.1\end{array}$ & - & - & - & \multirow[t]{2}{*}{$\begin{array}{l}\text { S. } E= \\
0.104\end{array}$} \\
\hline & $\begin{array}{c}\text { General } \\
\text { mean }\end{array}$ & 2.46 & 2.16 & 1.55 & 1.27 & 1.86 & - & - & - & \\
\hline
\end{tabular}


Table 2. Effect of famish and moisture of soil levels on $E$.vermiculata weight under laboratory conditions.

\begin{tabular}{|c|c|c|c|c|c|c|c|c|c|c|}
\hline \multirow[b]{2}{*}{$\begin{array}{c}\text { Soil } \\
\text { moisture } \\
\text { level }\end{array}$} & \multirow{2}{*}{$\begin{array}{r}\text { famish } \\
\text { level } \\
\text { Snail } \\
\text { age }\end{array}$} & \multirow[b]{2}{*}{$\mathrm{F} 1$} & \multirow[b]{2}{*}{ F2 } & \multirow[b]{2}{*}{ F3 } & \multirow[b]{2}{*}{$\mathrm{F} 4$} & \multirow[b]{2}{*}{$\begin{array}{c}\text { General } \\
\text { mean士 } \\
\text { S.E }\end{array}$} & \multicolumn{4}{|c|}{ Significance } \\
\hline & & & & & & & $6 m$ & $9 m$ & $14 m$ & \multirow{3}{*}{$\begin{array}{l}\text { L. S. } \\
\text { D } \\
0.05 \\
= \\
0.409\end{array}$} \\
\hline \multirow{4}{*}{$\begin{array}{c}80-85 \% \\
\text { soil } \\
\text { moisture }\end{array}$} & $\begin{array}{c}3 \\
\text { months }\end{array}$ & 1.09 & 0.93 & $\begin{array}{c}0 . \\
36\end{array}$ & 0.29 & $\begin{array}{c}0.67 \\
\pm 0.15\end{array}$ & $\begin{array}{c}++ \\
0.58 \\
\end{array}$ & $\begin{array}{l}+++ \\
1.72 \\
\end{array}$ & $\begin{array}{l}+++ \\
3.84 \\
\end{array}$ & \\
\hline & $\begin{array}{c}6 \\
\text { months }\end{array}$ & 1.62 & 1.52 & 1.07 & 0.78 & $1.25 \pm 0.15$ & - & +++1.14 & +++3.26 & \\
\hline & $\begin{array}{c}9 \\
\text { months }\end{array}$ & 3.14 & 2.94 & 1.95 & 1.56 & $2.39 \pm 0.15$ & - & - & +++2.12 & \multirow{2}{*}{$\begin{array}{l}\text { L.S.D } \\
0.01= \\
0.537\end{array}$} \\
\hline & $\begin{array}{c}14 \\
\text { months }\end{array}$ & 5.37 & 5.07 & 3.98 & $\begin{array}{l}3 . \\
61 \\
\end{array}$ & $4.51 \pm 0.15$ & - & - & - & \\
\hline \multicolumn{2}{|c|}{ General mean } & 2.81 & 2.62 & 1.84 & 1.56 & 2.21 & - & - & - & $\begin{array}{l}S . E= \\
0.148\end{array}$ \\
\hline \multirow{4}{*}{$\begin{array}{c}10-15 \% \\
\text { soil } \\
\text { moisture } \\
\text { (dry } \\
\text { soil) }\end{array}$} & $\begin{array}{c}3 \\
\text { months }\end{array}$ & 0.33 & 0.28 & 0.27 & 0.00 & $0.22 \pm 0.21$ & +0.55 & +++1.34 & +++3.23 & $\begin{array}{l}\text { L.S.D } \\
0.05= \\
0.578 \\
\end{array}$ \\
\hline & $\begin{array}{c}6 \\
\text { months }\end{array}$ & 1.45 & 0.88 & 0.54 & 0.36 & $0.81 \pm 0.21$ & - & ++0.75 & +++2.64 & $\begin{array}{l}\text { L.S.D } \\
0.01= \\
0.760 \\
\end{array}$ \\
\hline & $\begin{array}{c}9 \\
\text { months }\end{array}$ & 2.46 & 1.59 & 1.14 & 1.03 & $1.56 \pm 0.21$ & - & - & +++1.86 & \multirow{3}{*}{$\begin{array}{l}S . E= \\
0.209\end{array}$} \\
\hline & $\begin{array}{c}14 \\
\text { months }\end{array}$ & 4.19 & 4.06 & 3.07 & 2.48 & $3.45 \pm 0.21$ & - & - & - & \\
\hline \multicolumn{2}{|c|}{ General mean } & 2.11 & 1.70 & 1.26 & 0.97 & 1.51 & - & - & - & \\
\hline
\end{tabular}

Fig 1. Effect of dryness and starvation on death percentage of $E$. vermiculate
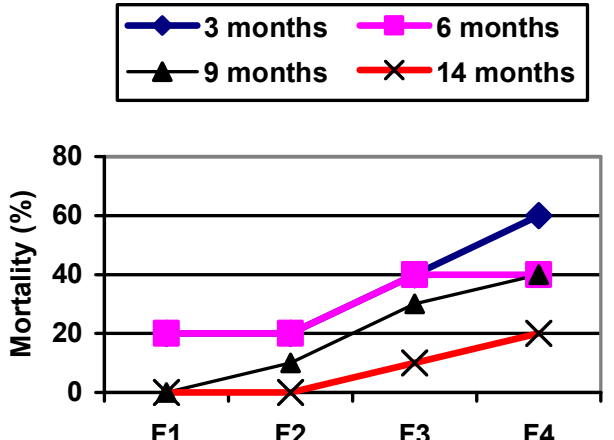

(A) Soil moisture $80-85 \%$
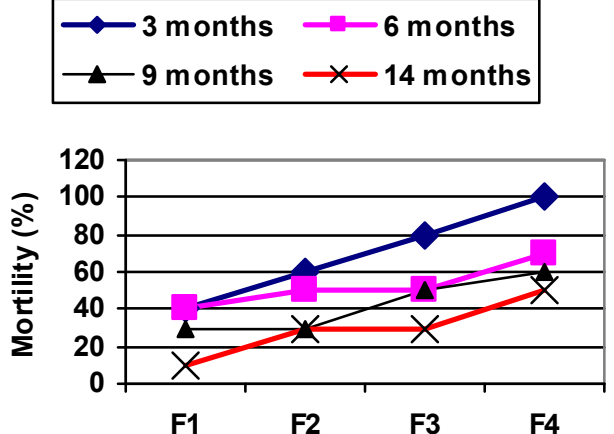

(B) Soil moisture $10-15 \%$ addition

$\mathrm{F} 1=$ Snails were fed every two days, $\mathrm{F} 2$ = Snails were feeding each week F3 $=$ Snails were fed each month, F4 = Snails were reared without food addition 


\section{2- Effect of starvation and moisture levels on E. vermiculata weight under laboratory Conditions:}

Results in table (2) showed that the effect of starvation levels were more pronounced on $E$. vermiculata ages lived in soil with $10-15 \%$ moisture. The weight of snail body at different stages decreased where the period of starvation was increased. Mean of weights were $0.36,1.03$ and $2.48 \mathrm{grm}$ for 6,9 and 14 months when snails stayed without food, respectively. On the other hand, the highest weights obtained when snails were feeding every two days under $80-85 \%$ soil moisture recording 1.09 , $1.62,3.14$ and $5.379 \mathrm{grm}$ for $3,6,9$ and 14 months, respectively.

Data in the same table (2) also cleared that the differences in weight lose were significant between 3 and 6 months while was highly significant between 3 and 9 or 14 months. On the other hand it was highly significant between 6 and 9 and 14 months in case of soil moisture $80-85 \%$. In case of dry soil, differences in the lose of weight were low significant between 3 and 6 months, and were highly significant between 3 and 9 or 3 and 14 months. Also, they were significant between 6 and 14 or 9 and 14 months.

From the previous results it was clear that the best conditions to rear snails were $80-85 \%$ soil moisture with feeding every two days.However starvation and dryness help to achieve the pest control.

The results obtained some what in agreement with Ghada. R. Y (2004) who mentioned that the highest weight of Monacha obstructa eggs was recorded when the snail bred in soil with moisture $75 \%$, but the weight was very little when the moisture was decreased to $25 \%$ in the soil. In addition the greatest weight of eggs was recorded for lettuce and cabbage and clover followed by cucumber at 75\% moisture.

\section{3- Effect of dryness and starvation on death percentage of E. vermiculata.}

Fig (1) indicated the results of the effect of famish and dryness on the death percentage of $E$. vermiculata. These results showed that, the highest mortality percentages were recorded when the different stages of snail were reared in dry soil with $10-15 \%$ moisture and without food addition. The percentages of mortality were $100,70,60$ and $50 \%$ for 3, 6, 9 and 14 months respectively, The lowest mortality $\%$ recorded when snail was fed every two days under $80-85 \%$ soil moisture, it gave 20 and $20 \%$ for 3 and 6 months age. No mortality recorded with 9 and 14 month stages. The percentages of mortality increased to $60,40,40$ and $20 \%$ for $3,6,9$ and 14 months stage, respectively, when the individuals reared without food additions and $80-85 \%$ soil moisture. Reviewing the obtained results it is clear that all stages of $E$. vermiculata snail affected significantly with the different four levels of starvation and soil moisture. The four ages of snail were in the best forms when they were living in 
soil with $80-85 \%$ moisture and feeding each two days, vice versa the individuals were in bad forms when reared without nourishing in dry soil particularly the young ages.

These finding are near with those recorded by Awad, et. al. (2009) who observed that, under field conditions the highest number of Monacha cantiana was recorded in clover moist soil, while the lowest was recorded in wheat dry soil. Also these data agree with Godan (1983) and El- Okda $(1979,1980)$ who reported that the highest number of snails were collected from moist locations.

\section{4- Effect of dryness and starvation on number and depth of eggs laid by $E$. vermiculata under laboratory conditions.}

Results in table (3) show the effect of food and moisture levels on number of $E$. vermiculata eggs, and the form of eggs either in solitary or in masses and also the depth of eggs in the soil under laboratory conditions. The mean number of eggs gave irregular results with the different food levels. With respect to the number of eggs it was clear that the increase of the period of starvation led to increase in solitary eggs while the recording mean number of solitary eggs gave 6.5, 9,17.5 and 20 eggs with the levels of feeding every two days, every week, every month and without food addition respectively. As for, eggs in masses the results in the same table (3) show that the increase in food additions (or lowering the period between diets) gave higher egg masses than starved snails and also the number of eggs in there masses increased with the increase of food addition. This mean that the egg production generally increase when the intervals between diets decrease. The mean numbers of obtained egg masses showing $2.5,2,1.5$ and 1.5 mass with the four levels of feeding ( F1, F2, F3 and F4) respectively. Also the numbers of eggs in the previous categories of feeding were 50, 47.5, 36 and 25 respectively. Concerning with the depth of egg laying, it was obvious that the increase of feeding make snails adults to lay their eggs in soil deeper than starved snail adults. The previous results is belonging to the snails were reared in soil with $80-85 \%$ moisture. On the other hand, in the case of soil moisture $10-15 \%$ the results were different with the previous in the case of $80-85 \%$ soils moisture whereas the solitary face of eggs increase with food increasing while approximately were no egg masses laid except with the two days level of feeding. 
Table 3. Effect of starvation and moisture level on depth, umber of solitary eggs, number of masses and number of eggs in mass laid by $E$. vermiculata adults under laboratory conditions.

\begin{tabular}{|c|c|c|c|c|c|}
\hline \multirow[b]{2}{*}{$\begin{array}{c}\text { soil } \\
\text { Moisture level }\end{array}$} & \multirow[b]{2}{*}{ starvation level } & \multirow[b]{2}{*}{$\begin{array}{l}\text { Mean No. of } \\
\text { Solitary eggs }\end{array}$} & \multicolumn{2}{|c|}{ Eggs in masses } & \multirow[b]{2}{*}{$\begin{array}{c}\text { Depth of eggs } \\
\text { in soil/ cm }\end{array}$} \\
\hline & & & $\begin{array}{c}\text { Mean No. of } \\
\text { masses }\end{array}$ & $\begin{array}{l}\text { Mean No. of } \\
\text { eggs in mass }\end{array}$ & \\
\hline \multirow{4}{*}{$80-85 \%$} & $\mathrm{~F} 1$ & 6.5 & 2.5 & 50 & 4.05 \\
\hline & F2 & 9 & 2 & 47.5 & 4.1 \\
\hline & F3 & 17.5 & 1.5 & 36 & 3.7 \\
\hline & $\mathrm{F} 4$ & 20 & 1.5 & 25 & 3.1 \\
\hline \multicolumn{2}{|c|}{ General Mean } & 13.25 & 1.88 & 39.63 & 3.74 \\
\hline \multirow{4}{*}{$\begin{array}{l}\text { Dry Soil } 10- \\
\qquad 15 \%\end{array}$} & F1 & 16.5 & 1 & 19 & 0.00 \\
\hline & $\mathrm{F} 2$ & 11.5 & 0.00 & 0.00 & 0.00 \\
\hline & F3 & 9.5 & 0.00 & 0.00 & 0.00 \\
\hline & $\mathrm{F} 4$ & 8 & 0.00 & 0.00 & 0.00 \\
\hline \multicolumn{2}{|c|}{ General mean } & 11.38 & 0.25 & 4.75 & 0.00 \\
\hline
\end{tabular}

Generally data cleared that the most pereferable circumstance for laying solitary eggs or eggs in masses was recorded when the snail were feeding every two days under $80-85 \%$ soil moisture. Also the obtained data showed that, adults of $E$. vermiculata laid their eggs into small pits when the soil moisture was $80-85 \%$, while it prefer laying their eggs on the surface when soil was dry. These results are in agreement with those recorded by Mohamed (1999) who found that the snail $E$. vermiculata deposits their eggs in holes and sometimes on the surface of soil, as well as the number of masses and number of eggs per mass was varied according to the type of soil.

\section{REFERENCES}

1. A wad, M.H.M., M.A. Osman and A.H. Hamad. 2009. Factors affecting the population fluctuations of terrestrial snails Monacha cantiana (Muller) and Succinea putris (Linnaeus) at faraskour district, Damietta Governorate, J. Agric. Sci. Mansoura Univ., 34(2): 1231- 1327.

2. El- Deeb , H. I., E. M. Ghamry, N. El-Hwashy and N. Essa. 1996. Relative a abundance of some land snails in certain Governorates of Egypt. J. Agric. Sci. Mansoura Univ., 21 (8): 2977-2983. 
3. El- Okda, M. K. 1979. Land snails of economic importance Alexandria region with some notes on the morphological features, classification, economic damage and population on namental or plants. Agric. Res. Rev., Egypt, 51 (1): 125-131.

4. El- Okda, M.K. 1980. Land snails of economic importance on vegetable crops at .Alexandria and reighboring regions . J. Agric. Res. 58 (1):79-86.

5. Ghada. R. y. 2004. Ecological And biological studies on some species of snails. M. Sc. Thesies, Fac. Agric., Benha uUniv., 204 pp.

6. Ghamry, E. M., H. I. El- Deeb and Al. H. Abdel. 1993. Efficiency of certain pesticides a gainst some land snails under field conditions at sharkia Governorate. Egypt. J Appl. Sci., 8 (6): 764-774.

7. Godan, D. 1983. Pest slugs and snails Biology and Control (translated by S. Gruber), Springer- Verlag, Berlin. 445 pp.

8. Hegab, A. M. I., E. M. Ghamry, S. A. A. El- Massry and Afaf, I. Hassan. 1999. Ecological studies on certain land snails in some localities at sharkia Governorate. Zagazig J. Agric. Res., 26(3B): 787 - 795.

9. Ismail, Sh. A.A. 2004. Ecological studies on the brown garden Snail, Eobania vermiculate (Muller) under laboratory and field conditions in Sharkia Governorate. Zagazig J. Agric. Res., 31(1): 293-305.

10. Kassab, A. and H. Daoud. 1994. Notes on the biology and control of economic importance land snails in U.A.R. Agric. Res. Reve. Min of Agric., UAR, 42:77-98.

11. Mahrous, M. E., M. H. Ibrahim and E. M. Abd- El- Aal. 2002. Control of certain land snails under field conditions in Sharkia Governorate. Egypttain Jornal of Agricultural Research 29:1041-1045.

12. Mohamed, M. F. 1999. Ecological and biological studies on land snails and slugs in Egypt. Ph.D. Thesis, Fac. Agric., Cairo Univ., 228 PP.

13. Notton D. 2006." Eobania vermiculata in UK" mollusk world 11:6. 


\section{تأثثر الجفاف والتجويع على بعض النواحى البيولوجية لقوقع الحدائق البني Eobania vermiculata}

غادة رفعت يوسف محمد - طلعت محمد سليمان قشطه و عبد المقفصود محمد ابو هاثم

$$
\text { قعم وقاية النبات ، كلية الزراعة بكشتهر ، جامعة بنها }
$$

تمت هذه الدر اسة لتوضيح الدور الذى تلعبه مستويات التغذيــة و الجفــاف علــى بعـض رض

الوظائف الحيوية لأربع أعمار مختلفة من قوقع الحدائق البني Eobania vermiculata وهي r ، 7 ، 9 ، ؛ 1 شهر تحت ظروف المعمل • وقد أوضحت النتائج أن أفضل البيئات لحياة جميع الأعمار

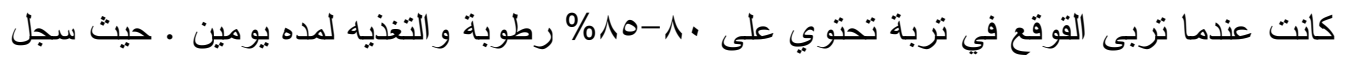
القوقع أعلى الأوزان لجميع الأعمار بينما سجلت أقل الأوزان عندما عاثت الأفر اد في تربــــة جافـــة

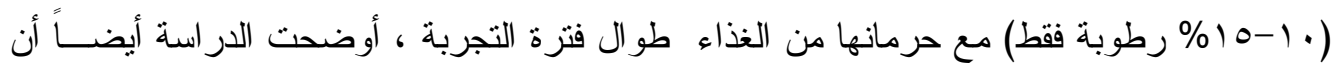

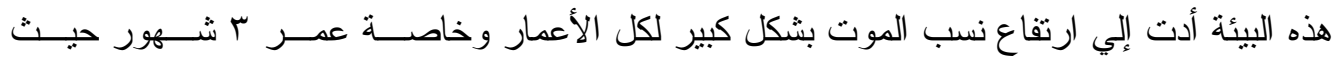
وصلت نسبة الموت إلي . . 1\%. كما أوضحت النتائج أن هنالك تأثير ملحوظ على عدد البيض الذى تضعه الأفر اد البالغة من هذا القوقع سو اء كان هذا البيض فردياً أو في كتل وكذلك عدد البيض داخل الكتلة الواحدة وعمق الكنل داخل التربة ـ وكانت أنسب البيئات لوضع عدد أكبر من كنل البيض هي

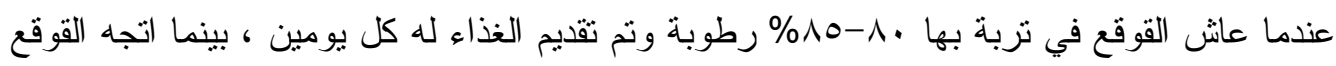
لوضع عدد بسيط من البيض على سطح التزبة في حالة التزبة الجافة وحرمانه من الغذاء. 